\title{
Interrelation of the FTO rs9939609 SNP and the DAT1 rs27072 SNP with Body Mass Index and Degree of Obesity in the Population of Yakuts
}

\author{
Nadezhda I. Pavlova, $\mathrm{PhD}^{1^{*}}$; Khariton A. Kurtanov, $\mathrm{PhD}^{1}$; Aleksandra T. Diakonova ${ }^{1}$; \\ Natalia A. Solovyeva, $\mathrm{PhD}^{1}$; Ljubov' Ah. Sydykova, $\mathrm{PhD}^{2,3}$; Tuiara N. Aleksandrova ${ }^{1}$; \\ Yulia A. Solovyeva ${ }^{1}$ \\ ${ }^{1}$ Yakut Science Center of Complex Medical Problems \\ ${ }^{2}$ M. K. Ammosov North-Eastern Federal University \\ ${ }^{3}$ Yakut Republican Clinical Hospital \\ Yakutsk, the Republic of Sakha (Yakutia), Russia
}

\begin{abstract}
The purpose of the present study was to evaluate a possible interrelation of the FTO rs 9939609 SNP and the DAT1 rs 27072 SNP with BMI and grade of obesity in the population of Yakuts

Materials and Methods: A total of 191 people of Yakut nationality were tested (143 women and 48 men). Two groups of subjects were formed: the control group (CG) with $\mathrm{BMI}<25 \mathrm{~kg} / \mathrm{m}^{2}$ and the obesity group (OG) with $\mathrm{BMI} \geq 30 \mathrm{~kg} / \mathrm{m}^{2}$. The study of the FTO rs9939609 SNP and the DAT1 rs27072 SNP was performed by PCR and restriction fragment length polymorphism.

Results: According to the results obtained from all persons surveyed, the frequency of the A risk allele of the FTO rs9939609 SNP was $27 \%$ with the AA genotype frequency of $9.4 \%$. Analysis of the distribution of alleles and genotypes of the DAT1 rs 27072 SNP showed the predominance of the wild-type G allele (90.8\%) and the GG genotype in all groups (82.7\%). Thus, in the Yakut population, a reliable relationship was found between the carriage of the A risk allele of the FTO SNP rs9939609 SNP with obesity and the degree of obesity. A significantly higher BMI was found in carriers of the wild-type G allele of the DAT1 rs27072 SNP, both in the heterozygous and homozygous forms than in the carriers of the homozygous AA genotype, which is probably related to the small number of people studied and requires careful research on larger samples of populations of Yakutia.(International Journal of Biomedicine. 2019;9(3):210-215.)
\end{abstract}

Key Words: BMI • obesity $\bullet$ the FTO gene $\bullet$ the DAT1 gene $\bullet$ eating disorders

\section{Introduction}

Until recently, it was believed that obesity mainly affects people in industrialized countries, but in recent years, obesity has spread around the world regardless of professional, social, geographical, sexual and age groups. This is mainly due to two factors: a decrease in the need for intense physical activity in the workplace and at home, which led to a decrease in the requirements for energy consumption; and the abundance, availability, attractiveness and relative cheapness of food, which increases due to commercial promotion. ${ }^{(1)}$ According to WHO (2016) among the working-age population, about two

\footnotetext{
*Corresponding author: Nadezhda I. Pavlova, PhD. Yakut Science Center of Complex Medical Problems. Yakutsk, the Republic of Sakha (Yakutia), Russia. E-mail: solnishko_84@inbox.ru
}

billion people were overweight; of these, over 650 million (about 13\% of the world's adult population) were obese. ${ }^{(2)}$

Yakutia is the coldest of the inhabited regions of the planet, with extreme climatic conditions, which in turn have resulted in peculiarities in the metabolism of the indigenous people. According to the research of L.E. Panina (2010), the influence of extreme conditions forms the polar metabolic type, which is characterized by lipid energy metabolism instead of carbohydrate energy metabolism, which in turn affects the nature of human nutrition. ${ }^{(3)}$

In recent years, due to industrialization, the nature of nutrition of indigenous people has changed from protein-lipid to carbohydrate-lipid. According to Darbasov et al. (2017), the intake of proteins and fats in the daily diet decreased by $13 \%$ and $18 \%$, respectively, while the proportion of carbohydrates increased to $65 \%{ }^{(4)}$ Among the indigenous population, the 
number of obese people has increased, due not only to changes in diet, but also to physical inactivity. ${ }^{(5)}$

One of the important factors in obesity pathogenesis is genetic predisposition. ${ }^{(6)}$ In 2007, a T2D GWAS identified multiple SNPs in the first intron of the FTO (fat mass and obesity-related) gene associated with disease and increased weight. Confirmation of this association with body mass index (BMI) was replicated in 13 independent cohorts totaling 38,759 participants..$^{(7)}$ A significant association of an SNP rs9939609 in the FTO gene with obesity in various ethnic populations of the world has been well studied (Figure 1). ${ }^{(8)}$

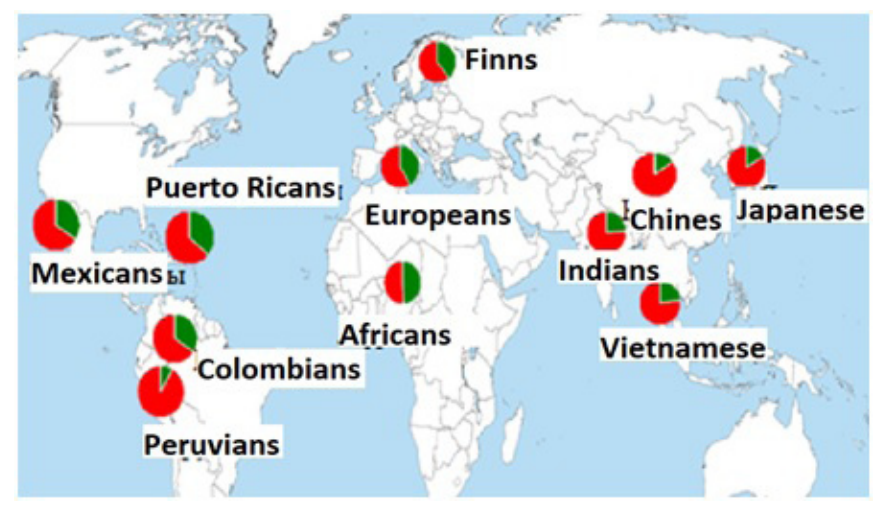

Fig. 1. Allelic polymorphism of the FTO rs9939609 SNP in various populations.

Red color - T allele, green color - A allele. Data obtained from the database of the project "1000 genomes". (8)

Gerken et al. ${ }^{(9)}$ showed that FTO shares sequence motifs with $\mathrm{Fe}(\mathrm{II})-$ and 2-oxoglutarate-dependent oxygenases. Studies of wild-type mice indicate that Fto messenger RNA (mRNA) is most abundant in the brain, particularly in hypothalamic nuclei governing energy balance, and that Fto mRNA levels in the arcuate nucleus are regulated by feeding and fasting. The FTO SNPs associated with adiposity are intronic and may exert functional effects through altered expression of FTO mRNA.

Frayling et al. ${ }^{(7)}$ reported that individuals homozygous for the A "risk" allele weigh approximately $3 \mathrm{~kg}$ more and have a 1.67 -fold increased risk of developing obesity, while heterozygous carriers display an intermediate weight gain of $1.5 \mathrm{~kg}$.

Subjects homozygous for the A risk allele of rs9939609 eat significantly more, ${ }^{(10,11)}$ have reduced satiety, ${ }^{(12-14)}$ prefer higher caloric food and have a higher fat mass ${ }^{(15,16)}$ than subjects homozygous for the $\mathrm{T}$ allele.

Also contributing to the development of obesity are disruptions in the functioning of the dopaminergic system receptor genes leading to impaired appetite control, nutritional motivation and reward as components of eating behavior. ${ }^{(17)}$ The dopamine transporter (DAT) is the most relevant neurotransmitter transporter, controlling both extracellular and intracellular concentrations of dopamine. ${ }^{(18)}$ Experts believe the action of the neurotransmitter dopamine on the brain's "common reward pathway" is primarily accountable for hedonic motivations for food intake. ${ }^{(19,20)}$ The genetically determined action and availability of dopamine on this pathway appear to determine individual variations in the tendency to overeat and vulnerability to binge eating disorders and obesity. The DAT protein is coded by SLC6A3 gene (or DAT1) which spans $>60 \mathrm{~kb}$ and is located in human chromosome 5 (5p15.3). ${ }^{(21,22)}$ The SLC6A3 contains 15 exons separated by 14 introns, and the protein-coding portion excludes exon 1 and ends near the beginning of exon 15. Polymorphisms in the DAT1 locus are involved in gene expression, transcriptional activity and protein availability. The works of domestic and foreign researchers have shown the relationship of dependence on nicotine, alcohol and other psychoactive substances with the DAT1 gene. ${ }^{(23-25)}$ Shinohara et al. ${ }^{(26)}$ showed that the association between the $D A T 1$ VNTR and binge-eating behaviour indicates that dysregulation of dopamine reuptake may act as a common pathophysiologic mechanism in eating disorders with bingeeating behaviour and in disorders related to substance use (Figure 2).

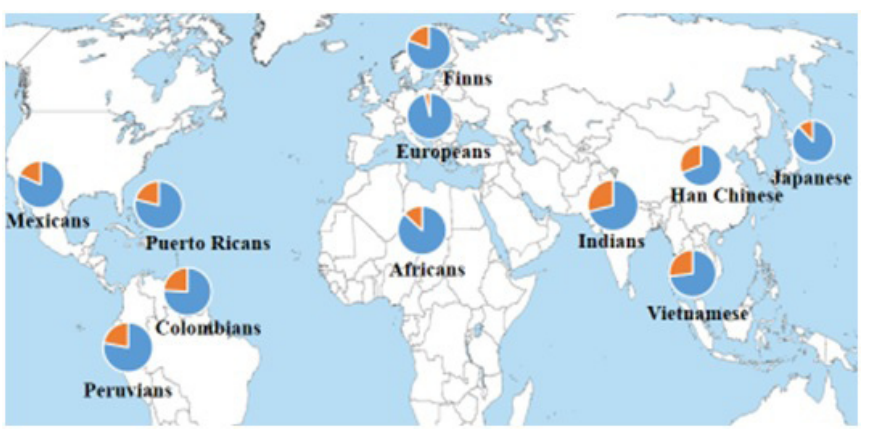

Fig. 2. Allelic polymorphism of the DAT1 rs27072 SNP in various populations.

Orange color $-A$ allele, blue color $-G$ allele. Data obtained from the database of the project "1000 genomes". ${ }^{(8)}$

The purpose of the present study was to evaluate a possible interrelation of the FTO rs9939609 SNP and the $D A T 1$ rs 27072 SNP with BMI and grade of obesity in the population of Yakuts.

\section{Materials and Methods}

The study was approved by the Ethics Committee of the Yakut Science Center of Complex Medical Problems (YSC CMP). All patients gave their written informed consent.

A total of 191 people of Yakut nationality were tested (143 women and 48 men). The ethnic origin was considered to the third generation. The study was performed after participants signed a written, informed consent. Two groups of subjects were formed: the control group (CG) (70 women and $21 \mathrm{men}$ ) with $\mathrm{BMI}<25 \mathrm{~kg} / \mathrm{m}^{2}$ and the obesity group (OG) (73 women and $27 \mathrm{men}$ )-with $\mathrm{BMI} \geq 30 \mathrm{~kg} / \mathrm{m}^{2}$. OG was divided into two subgroups: obesity grade 1 (BMI 30.0-34.9 kg/m²) (OGG1) and obesity grades 2 and $3\left(\mathrm{BMI} \geq 35 \mathrm{~kg} / \mathrm{m}^{2}\right)(\mathrm{OGG} 2-3)$.

Genotyping of the FTO rs9939609 SNP and the DAT1 rs27072 SNP was performed in the laboratory of molecular genetics at YSC CMP. Genomic DNA samples were isolated from the peripheral blood leukocytes using a commercial DNA kit, Excel biotech (Yakutsk, Russia). The study of the FTO 
rs9939609 SNP and the DAT1 rs27072 SNP was performed by PCR and restriction fragment length polymorphism. The conditions of amplification and restriction are presented in Table 1. Samples after PCR-RFLP were visualized using ethidium bromide-stained gel electrophoresis (2-4\% agarose) and a UV transilluminator (Vilber Lourmat, France).

Table 1. Conditions for PCR-RFLP analysis

\begin{tabular}{|c|c|c|c|c|c|}
\hline Gene & Primer Sequence & $\begin{array}{c}\text { LA, } \\
b p\end{array}$ & AT & $\mathrm{RE}$ & $\begin{array}{l}\text { RFL, } \\
\text { bp }\end{array}$ \\
\hline \multirow{2}{*}{ FTO } & $\begin{array}{l}\text { F:5'-AACTGGCTCTTGAA } \\
\text { TGAAATAGGATTCAGA-3' }\end{array}$ & \multirow{2}{*}{182} & \multirow{2}{*}{$58^{\circ} \mathrm{C}$} & \multirow{2}{*}{ Zrm I } & \multirow{2}{*}{$\begin{array}{c}\text { AA: } 154,28 \\
\text { AT: } 154,28,182 \\
\text { TT: } 182\end{array}$} \\
\hline & $\begin{array}{l}\text { R:5'-AGAGTAACAGAGAC } \\
\text { TATCCAAGTGCAGTAC-3' }\end{array}$ & & & & \\
\hline \multirow{2}{*}{$D A T 1$} & $\begin{array}{l}\text { F: 5'-ACGGGGATTCT } \\
\text { CAGCAGGTG-3' }\end{array}$ & \multirow{2}{*}{217} & \multirow{2}{*}{$62^{\circ} \mathrm{C}$} & \multirow{2}{*}{ MspI } & \multirow{2}{*}{$\begin{array}{c}\text { AA: } 217 \\
\text { AG: } 217,137,80 \\
\text { GG: } 137,80\end{array}$} \\
\hline & $\begin{array}{l}\text { R: 5'-TACAGCAACAC } \\
\text { AAGACACGG-3' }\end{array}$ & & & & \\
\hline
\end{tabular}

LA- length of amplificate; AT- annealing temperature; $R E$ - restriction endonuclease; RFL- restriction fragment length

Interpretation of the results of genotyping was performed on the basis of various template patterns for the FTO gene: the $\mathrm{T}$ allele produced a $182 \mathrm{bp}$ band and the A allele produced 154 and 28 bp bands. Polyacrylamide gel picture (Fig. 3) showing digested PCR products for the FTO gene: AT genotype (182, 154 and $28 \mathrm{bp}$ ), TT genotype (182 bp) and AA genotype (154 and $28 \mathrm{bp}$ ). For the DATl gene, the interpretation of the results of genotyping was as follows: the $\mathrm{G}$ allele produced 137 and 80 bp bands and the A allele produced a 217 bp band. Polyacrylamide gel picture (Fig. 4) showing digested PCR products for DAT1 gene: GG genotype (137 and $80 \mathrm{bp}$ ), AG genotype (217, 137 and $80 \mathrm{bp}$ ), and AA genotype (217 bp) (Figure 4).

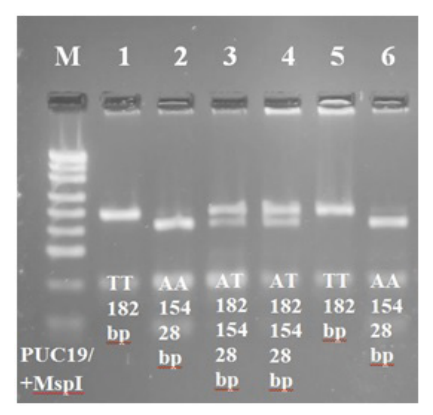

Fig. 3. Polyacrylamide gel electrophoresis of the FTO gene. $M$ - marker pUC19/+Msp I.

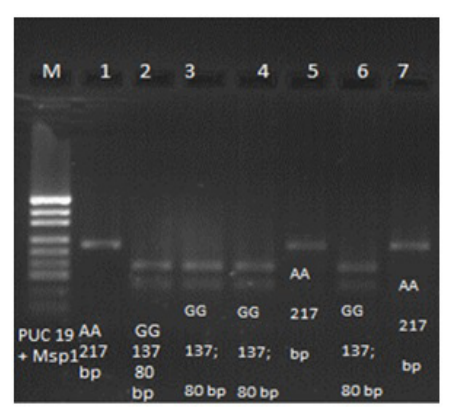

Fig. 4. Polyacrylamide gel electrophoresis of the DAT1 gene. $M$ - marker pUC19/+Msp I.
Statistical analysis was performed using the Statistica 10.0 software package (StatSoft Inc, USA). For descriptive analysis, results are presented as mean (M) \pm standard error of the mean (SEM). Multiple comparisons were performed with one-way ANOVA and Tukey's HSD Posthoc Test. Differences in the allele distribution between the two groups were assessed by $\chi 2$ - test with Yates correction. Odds ratios (ORs) and 95\% confidence intervals (CIs) were calculated. A probability value of $P<0.05$ was considered statistically significant.

\section{Results and Discussion}

According to the results obtained from all persons surveyed, the frequency of the A risk allele of the FTO rs9939609 SNP was $27 \%$ with the AA genotype frequency of $9.4 \%$ (Table 2). In men, the A risk allele was slightly more common than in the group of women $(\mathrm{OR}=1.061$; $95 \% \mathrm{CI}=0.62-1.816 ; P=0.938)$. Since the differences in the frequencies of alleles and genotypes in men and women were not significant, and the confidence interval showed a wide range, the samples of the compared groups were not divided by gender.

Table 2. The frequencies of alleles and genotypes of the FTO rs9939609 SNP with the calculation of OR in studied groups

\begin{tabular}{|c|c|c|c|c|c|c|c|}
\hline \multirow{2}{*}{ Group } & \multicolumn{3}{|c|}{$\begin{array}{l}\text { The distribution } \\
\text { of genotypes, } \%\end{array}$} & \multicolumn{2}{|c|}{$\begin{array}{c}\text { Allele } \\
\text { frequency, } \%\end{array}$} & \multicolumn{2}{|c|}{ OR for risk allele $(A)$} \\
\hline & AA & AT & $\mathrm{TT}$ & A & $\mathrm{T}$ & $\begin{array}{c}\text { OR } \\
(95 \% \mathrm{CI})\end{array}$ & $\mathrm{P}$ \\
\hline $\begin{array}{l}\text { All surveyed } \\
(n=191)\end{array}$ & 9.4 & 35.1 & 55.5 & 27 & 73 & - & - \\
\hline \multicolumn{8}{|c|}{ OR depending on gender } \\
\hline $\begin{array}{l}\text { All women } \\
(\mathrm{n}=143)\end{array}$ & 8.4 & 34.3 & 57.3 & 25.5 & 74.5 & \multirow{2}{*}{$\begin{array}{c}1.061 \\
(0.620-1.816)\end{array}$} & \multirow{2}{*}{0.93} \\
\hline $\begin{array}{l}\text { All men } \\
(\mathrm{n}=48)\end{array}$ & 6.7 & 40.0 & 53.3 & 26.7 & 73.3 & & \\
\hline \multicolumn{8}{|c|}{ OR in OG relative to CG and depending on the obesity grade } \\
\hline $\begin{array}{l}\mathrm{CG} \\
(\mathrm{n}=91)\end{array}$ & 8.8 & 31.9 & 59.3 & 24.7 & 75.3 & - & - \\
\hline $\begin{array}{l}\text { OG } \\
(n=100)\end{array}$ & 10.0 & 38.0 & 52.0 & 29.0 & 71.0 & $\begin{array}{c}1.244 \\
(0.789-1.959)\end{array}$ & 0.409 \\
\hline $\begin{array}{l}\text { OGG1 } \\
(\mathrm{n}=69)\end{array}$ & 5.8 & 37.7 & 56.5 & 24.6 & 75.4 & $\begin{array}{c}0.995 \\
(0.596-1.663)\end{array}$ & 0.910 \\
\hline \multirow{2}{*}{$\begin{array}{l}\text { OGG2-3 } \\
(n=31)\end{array}$} & \multirow{2}{*}{19.4} & \multirow{2}{*}{38.7} & \multirow{2}{*}{41.9} & \multirow{2}{*}{38.7} & \multirow{2}{*}{61.3} & $\begin{array}{c}1.923 \\
(1.043-3.546)^{*} \\
\end{array}$ & 0.051 \\
\hline & & & & & & $\begin{array}{c}1.932 \\
(1.017-3.668)^{* *}\end{array}$ & 0.063 \\
\hline
\end{tabular}

*-in relation to $C G$; **-in relation to $O G G 1$

In OG, the A risk allele was more common (29\%) than in CG (24.7\%) $(\mathrm{OR}=1.244,95 \% \mathrm{CI}=0.789-1.959, P=0.409)$. We found that the number of people with the A risk allele in OGG23 exceeded that in OGG1 (24.6\%) and CG $(24.7 \%)$ by $14.1 \%$ and $14 \%(\mathrm{OR}=1.923,95 \% \mathrm{CI}=1.043-3.546, P=0.051)$ and $14 \%$ $(\mathrm{OR}=1.932,95 \% \mathrm{CI}=1.017-3.668, P=0.06)$, respectively.

Analysis of the distribution of alleles and genotypes of the DAT1 rs27072 SNP showed the predominance of the wildtype $\mathrm{G}$ allele and the GG genotype in all groups (Table 3).

In women, a slightly higher frequency of the $\mathrm{G}$ allele was observed $(\mathrm{OR}=1.413,95 \% \mathrm{CI}=0.664-3.004, P=0.486)$ 
than in men. Since the differences in the frequencies of alleles and genotypes in men and women were not significant, and the confidence interval showed a wide range, the samples of the compared groups were not divided by gender. When comparing the sample with persons with normal BMI and obesity with different degrees, no significant differences were found.

Table 3. The frequencies of alleles and genotypes of the DAT1 rs27072 SNP with the calculation of OR in studied groups

\begin{tabular}{|c|c|c|c|c|c|c|c|}
\hline \multirow{2}{*}{ Group } & \multicolumn{3}{|c|}{$\begin{array}{l}\text { The distribution } \\
\text { of genotypes, } \%\end{array}$} & \multicolumn{2}{|c|}{$\begin{array}{c}\text { Allele } \\
\text { frequency, } \%\end{array}$} & \multicolumn{2}{|c|}{ OR for the $G$ allele } \\
\hline & AA & $\mathrm{AG}$ & GG & A & G & OR $(95 \% \mathrm{CI})$ & $\mathrm{P}$ \\
\hline $\begin{array}{l}\text { All surveyed } \\
(\mathrm{n}=191)\end{array}$ & 1.0 & 16.2 & 82.7 & 9.2 & 90.8 & - & - \\
\hline \multicolumn{8}{|c|}{ OR depending on gender } \\
\hline $\begin{array}{l}\text { All women } \\
(n=143)\end{array}$ & 1.4 & 14.0 & 84.6 & 8.4 & 91.6 & \multirow{2}{*}{$\begin{array}{c}1.413 \\
(0.664-3.004)\end{array}$} & \multirow{2}{*}{0.486} \\
\hline $\begin{array}{l}\text { All men } \\
(n=48)\end{array}$ & 0 & 22.9 & 77.1 & 11.5 & 88.5 & & \\
\hline \multicolumn{8}{|c|}{ OR in OG relative to CG and depending on the obesity grade } \\
\hline $\begin{array}{l}\mathrm{CG} \\
(\mathrm{n}=91)\end{array}$ & 2.2 & 9.9 & 87.9 & 7.1 & 92.9 & - & - \\
\hline $\begin{array}{l}\text { OG } \\
(n=100)\end{array}$ & 0.0 & $22 ., 0$ & 78.0 & 11.0 & 89.0 & $\begin{array}{c}0.622 \\
(0.304-1.275)\end{array}$ & 0.260 \\
\hline $\begin{array}{l}\text { OGG1 } \\
(\mathrm{n}=69)\end{array}$ & 0.0 & 27.5 & 72.5 & 13.8 & 86.2 & $\begin{array}{c}0.482 \\
(0.229-1.013)\end{array}$ & 0.077 \\
\hline \multirow{2}{*}{$\begin{array}{l}\text { OGG2-3 } \\
(\mathrm{n}=31)\end{array}$} & \multirow{2}{*}{0.0} & \multirow{2}{*}{9.7} & \multirow{2}{*}{90.3} & \multirow{2}{*}{4.8} & \multirow{2}{*}{95.2} & $\begin{array}{c}1,513 \\
(0.416-5.495)^{*}\end{array}$ & 0.737 \\
\hline & & & & & & $\begin{array}{c}3.140 \\
(0.893-11.037) * *\end{array}$ & 0.105 \\
\hline
\end{tabular}

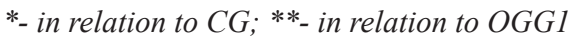

The BMI analysis depending on the genotypes of the FTO rs9939609 SNP and the DAT1 rs27072 SNP are presented in Table 4. The highest BMI scores for the FTO rs9939609 SNP were individuals homozygous for the A allele (AA) $(P=0.0002)$. According to the results of the analysis of the $D A T 1$ rs27072 SNP, a high BMI was observed in individuals with the heterozygous AG genotype $(P=0.0000)$. In persons with the heterozygous AT genotype for the FTO SNP rs9939609, BMI indices were significantly higher $(P=0.0064)$ than in individuals with a homozygous TT genotype. In terms of the DAT1 rs27072 SNP, the carrier state of the $G$ allele was associated with significantly high rates of $\mathrm{BMI}$ in comparison with the homozygous AA genotype, as the heterozygous $A G$ genotype $(\mathrm{P}=0.0000)$ and the homozygous GG genotype $(P=0.0000)$.

An analysis of the distribution of combinations of genotypes showed the predominance of people with the FTO rs9939609(TT)+DAT1rs27072(GG) combination (46\%) (Table 5).
In OG, the combinations of $F T O$ rs $9939609(\mathrm{AA})+D A T 1$ rs27072(GG) $(\mathrm{OR}=1.068,95 \% \mathrm{CI}=0.690-1.654, P=0.970)$, FTO rs9939609(AT)+DAT1rs27072(AG) $(\mathrm{OR}=1.563 ; 95 \%$ $\mathrm{CI}=1.146-2.131 ; P=0.079)$, and FTOrs9939609(TT) $+D A T l$ rs 27072(AG) $(\mathrm{OR}=1.265 .95 \% \mathrm{CI}=0.865-1.850 . P=0.416)$ were more common than in CG.

Table 4. BMI depending on the genotypes of the FTO rs9939609 SNP and the DAT1 rs27072 SNP

\begin{tabular}{|c|c|c|c|c|c|c|}
\hline \multirow[b]{2}{*}{$\stackrel{凶}{\tilde{d}}$} & \multicolumn{3}{|c|}{$\begin{array}{c}\text { Genotypes of } \\
\text { the FTO rs9939609 SNP }\end{array}$} & \multicolumn{3}{|c|}{$\begin{array}{c}\text { Genotypes of } \\
\text { the } D A T 1 \text { rs27072 SNP }\end{array}$} \\
\hline & $\underset{(n=18)}{\text { AA }}$ & $\underset{(\mathrm{n}=67)}{\mathrm{AT}}$ & $\begin{array}{c}\mathrm{TT} \\
(\mathrm{n}=106)\end{array}$ & $\begin{array}{c}\text { AA } \\
(n=2)\end{array}$ & $\underset{(\mathrm{n}=31)}{\mathrm{AG}}$ & $\underset{(n=158)}{G G}$ \\
\hline $\mathrm{SIV}$ & $29.55 \pm 1.85$ & $28.47 \pm 0.14$ & $27.19 \pm 0.13$ & $18.81 \pm 0.29$ & $29.73 \pm 0.18$ & $27.61 \pm 0.11$ \\
\hline 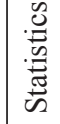 & \multicolumn{3}{|c|}{$\begin{array}{l}\mathrm{F}=8.8112, \mathrm{P}=0.0002 \\
\mathrm{P}_{\text {AA-AT }}=0.2773=0.0017 \mathrm{P}_{\text {AT-TT }}=0.0064 \\
\mathrm{P}_{\text {AA-TT }}=0.00\end{array}$} & \multicolumn{3}{|c|}{$\begin{array}{l}\mathrm{F}=80.2409, \mathrm{P}=0.0000 \\
\mathrm{P}_{\mathrm{AA}-\mathrm{AG}}=0.0000 \\
\mathrm{P}_{\mathrm{AA}-\mathrm{GG}}=0.0000 \mathrm{P}_{\mathrm{AG}-\mathrm{GG}}=0.0000\end{array}$} \\
\hline
\end{tabular}

Table 5. The distribution of the combinations of genotypes of the FTO gene and the DAT1 gene according to BMI

\begin{tabular}{|c|c|c|c|c|c|c|c|c|}
\hline \multirow{3}{*}{ Index } & Gene & \multicolumn{7}{|c|}{ Combination of genotypes } \\
\hline & FTO & AA & AT & AT & AT & TT & TT & $\mathrm{TT}$ \\
\hline & $D A T 1$ & GG & AA & $\mathrm{AG}$ & GG & AA & $\mathrm{AG}$ & GG \\
\hline \multicolumn{2}{|c|}{$\begin{array}{l}\text { Distribution } \\
\text { of genotypes } \\
\text { in total, } \mathrm{n}(\%)\end{array}$} & $\begin{array}{c}18 \\
(9.5)\end{array}$ & $\begin{array}{c}1 \\
(0.5)\end{array}$ & $\begin{array}{c}14 \\
(7.3)\end{array}$ & $\begin{array}{c}52 \\
(27.2)\end{array}$ & $\begin{array}{c}1 \\
(0.5)\end{array}$ & $\begin{array}{c}17 \\
(8.9)\end{array}$ & $\begin{array}{c}88 \\
(46.1)\end{array}$ \\
\hline \multicolumn{2}{|c|}{$\begin{array}{l}\text { Distribution } \\
\text { of genotypes } \\
\text { in CG, } \mathrm{n}(\%)\end{array}$} & $\begin{array}{c}8 \\
(8.8)\end{array}$ & $\begin{array}{c}1 \\
(1.1)\end{array}$ & $\begin{array}{c}3 \\
(3.3)\end{array}$ & $\begin{array}{c}25 \\
(27.5)\end{array}$ & $\begin{array}{c}1 \\
(1.1)\end{array}$ & $\begin{array}{c}6 \\
(6.6)\end{array}$ & $\begin{array}{c}47 \\
(51.6)\end{array}$ \\
\hline \multicolumn{2}{|c|}{$\begin{array}{l}\text { Distribution } \\
\text { of genotypes } \\
\text { in OG, } \mathrm{O}(\%)\end{array}$} & $\begin{array}{c}10 \\
(10)\end{array}$ & 0 & $\begin{array}{c}11 \\
(11)\end{array}$ & $\begin{array}{l}27 \\
(27)\end{array}$ & 0 & $\begin{array}{c}11 \\
(11)\end{array}$ & $\begin{array}{c}41 \\
(41)\end{array}$ \\
\hline \multicolumn{2}{|c|}{$\begin{array}{l}\text { OR } \\
(95 \% \mathrm{CI})\end{array}$} & $\begin{array}{l}1.068 \\
(0.690- \\
1.654)\end{array}$ & 0 & $\begin{array}{l}1.563 \\
(1.146- \\
2.131)\end{array}$ & $\begin{array}{l}0.989 \\
(0.728- \\
1.342)\end{array}$ & 0 & $\begin{array}{l}1.265 \\
(0.865- \\
1.850)\end{array}$ & $\begin{array}{l}0.813 \\
(0.615- \\
1.075)\end{array}$ \\
\hline \multicolumn{2}{|c|}{ P-value } & 0.970 & 0.963 & 0.079 & 0.929 & 0.963 & 0.416 & 0.184 \\
\hline \multicolumn{2}{|c|}{$\begin{array}{l}\text { Average } \\
\text { BMI }\end{array}$} & $\begin{array}{l}29.55 \\
\pm 1.85\end{array}$ & 18.52 & $\begin{array}{l}31.77 \\
\pm 2.19\end{array}$ & $\begin{array}{l}27.77 \\
\pm 0.19\end{array}$ & 19.1 & $\begin{array}{c}28.05 \\
\pm 1.2\end{array}$ & $\begin{array}{l}27.12 \\
\pm 0.15\end{array}$ \\
\hline
\end{tabular}

Evaluation of BMI with a combination of carriers of different genotypes of both genes showed that the highest rates $(31.77 \pm 2.19)$ were observed in the group of people with a combination of heterozygous AT genotype for the FTO SNP rs9939609 and heterozygous AG genotype for the DAT1 SNP rs27072. Their BMI was significantly higher than in people with a combination of the TT genotype for the FTO SNP rs9939609 and the GG genotype for the DAT1 SNP rs27072 (27.12 \pm 0.15$)$. 


\section{Conclusion}

Thus, in the Yakut population, a reliable relationship was found between the carriage of the A risk allele of the FTO SNP rs9939609 SNP with obesity and the degree of obesity. Thus, the number of carriers of the A allele in OGG2-3 exceeds the number of carriers of the A allele in OGG1 $(\mathrm{OR}=1.932$, 95\% $\mathrm{CI}=1.017-3.668, P=0.063)$ and $\mathrm{CG}(\mathrm{OR}=1.923,95 \%$ $\mathrm{CI}=1.043-3.546, P=0.051)$. In addition, in carriers of the $A T$ genotype of the FTO SNP rs9939609 SNP BMI was higher than in carriers of the TT genotype.

Analysis of the distribution of allele and genotype frequencies for the DAT1 rs27072 SNP in CG, OGG1, and OGG2-3 did not reveal any significant differences. Comparing the BMI index depending on the genotype, a significantly higher BMI was found in carriers of the wild-type $G$ allele, both in the heterozygous and homozygous forms than in the carriers of the homozygous $A A$ genotype, which is probably related to the small number of people studied and requires careful research on larger samples of populations of Yakutia.

The combination of different genotypes of both genes showed that the highest rates of BMI were observed in a group of people with the FTO SNP rs9939609(AT)+DAT1 SNP rs27072(AG) combination, which was significantly higher than in people with the FTO SNP rs9939609(TT)+DAT1 SNP rs27072(GG) combination.

\section{Competing Interests} interests.

The authors declare that they have no competing

\section{References}

1. O'Rahilly S, Farooqi IS. Human obesity: a heritable neurobehavioral disorder that is highly sensitive to environmental conditions. Diabetes. 2008;57(11): 2905-10. doi: $10.2337 / \mathrm{db} 08-0210$.

2. World Health Organization. Obesity and overweight. Available from: https://www.who.int/news-room/fact-sheets/ detail/obesity-and-overweight

3. Panin LE. [Homeostasis and the problems of circumpolar medicine. (Methodological Aspects of Adaptation)]. Bulletin of the Siberian Branch of the Russian Academy of Medical Sciences. 2010;3(30):6-11. [Article in Russian].

4. Darbasov VR, Baisheva VM, Fedorova EJa, Ohlopkov MN. [Features of the development of the food market of Yakutia: assessment of the level of food consumption and food supply of the population]. Regional Economics and Management: electronic scientific journal. 2017; 2(50). [Article in Russian].

5. Bojko NN. [Wake up the internal doctor]. Moscow: Interregional public fund "Home country"; 2011. [In Russian]. 6. Hebebrand J, Sommerlad C, Geller F, Görg T, Hinney A. The genetics of obesity: practical implications. Int J Obes Relat Metab Disord. 2001;25 Suppl 1:S10-8.

7. Frayling TM, Timpson NJ, Weedon MN, Zeggini E, Freathy $\mathrm{RM}$, Lindgren CM, et al. A common variant in the FTO gene is associated with body mass index and predisposes to childhood and adult obesity. Science. 2007;316(5826): 889-94.
8. Prakash J, Mittal B, Srivastava A, Awasthi S, Srivastava N. Association of FTO rs9939609 SNP with Obesity and Obesity-Associated Phenotypes in a North Indian Population. Oman Med J. 2016;31(2):99-106. doi: 10.5001/omj.2016.20

9. Gerken T, Girard CA, Tung YC, Webby CJ, Saudek V, Hewitson KS, et al. The obesity-associated FTO gene encodes a 2-oxoglutarate-dependent nucleic acid demethylase. Science. 2007;318(5855):1469-72. doi: 10.1126/science.1151710.

10. Speakman JR, Rance KA, Johnstone AM. Polymorphisms of the FTO gene are associated with variation in energy intake, but not energy expenditure. Obesity (Silver Spring). 2008;16(8):1961-5. doi: 10.1038/oby.2008.318.

11. Wardle J, Llewellyn C, Sanderson S, Plomin R. The FTO gene and measured food intake in children. Int J Obes (Lond). 2009;33(1):42-5. doi: 10.1038/ijo.2008.174.

12. Wardle J, Carnell S, Haworth CM, Farooqi IS, O'Rahilly $\mathrm{S}$, Plomin R. Obesity associated genetic variation in FTO is associated with diminished satiety. J Clin Endocrinol Metab. 2008;93(9):3640-3. doi: 10.1210/jc.2008-0472.

13. den Hoed M, Westerterp-Plantenga MS, Bouwman FG, Mariman EC, Westerterp KR. Postprandial responses in hunger and satiety are associated with the rs 9939609 single nucleotide polymorphism in FTO. Am J Clin Nutr.2009;90(5):1426-32. doi: 10.3945/ajen.2009.28053.

14. Tanofsky-Kraff M, Han JC, Anandalingam K, Shomaker LB, Columbo KM, Wolkoff LE, et al. The FTO gene rs9939609 obesity-risk allele and loss of control over eating. Am J Clin Nutr. 2009;90(6):1483-8. doi: 10.3945/ ajcn.2009.28439.

15. Cecil JE, Tavendale R, Watt $P$, Hetherington MM Palmer $\mathrm{CN}$. An obesity-associated FTO gene variant and increased energy intake in children. N Engl J Med. 2008; 359(24):255866. doi: 10.1056/NEJMoa0803839.

16. Timpson NJ, Emmett PM, Frayling TM, Rogers I, Hattersley AT, McCarthy MI, et al. The fat mass- and obesityassociated locus and dietary intake in children. Am J Clin Nutr. 2008;88(4):971-8.

17. Novikova EA, Bairova TA, Rychkova LV. [Correlation of the 48bp VNTR locus of DRD4 gene with overweight/ obesity]. Acta Biomedica Scientifica. 2017;2(5(1)):63-68 doi: 10.12737/article_59e85bc95a4e77.95444674. [Article in Russian].

18. Salatino-Oliveira A, Rohde LA, Hutz MH. The dopamine transporter role in psychiatric phenotypes. Am J Med Genet B Neuropsychiatr Genet. 2018;177(2):211-231. doi: 10.1002/ ajmg.b.32578.

19. Small DM, Jones-Gotman M, Dagher A. Feedinginduced dopamine release in dorsal striatum correlates with meal pleasantness ratings in healthy human volunteers. Neuroimage. 2003;19(4):1709-15.

20. Norgren R, Hajnal A, Mungarndee SS. Gustatory reward and the nucleus accumbens. Physiol Behav. 2006;89(4):531-5.

21. Haddley K, Vasiliou AS, Ali FR, Paredes UM, Bubb VJ, Quinn JP. Molecular genetics of monoamine transporters: relevance to brain disorders. Neurochem Res. 2008;33(4):652-67.

22. Vandenbergh DJ, Persico AM, Uhl GR. A human dopamine transporter cDNA predicts reduced glycosylation, displays a novel repetitive element and provides racially-dimorphic TaqI RFLPs. Brain Res Mol Brain Res. 1992;15(1-2):161-6.

23. Sander T, Harms H, Podschus J, Finckh U, Nickel B, Rolfs A, et al. Allelic association of a dopamine transporter 
gene polymorphism in alcohol dependence with withdrawal seizures or delirium. Biol Psychiatry. 1997;41(3):299-304. doi:10.1111/j.1530-0277.2011.01509.x.

24. Diakonova AT, Pavlova NI, Solovyeva NA, Varlamova MA, Alexandrova TN, Kurtanov KhA. Molecular-genetic analysis of the connection of the SLC6A3 gene with nicotine addiction in Yakutia. Yakut Medical Journal. 2018;4(64):6-9 doi 10.25789/YMJ.2018.64.01

25. Ohmoto M, Takahashi T, Kubota Y, Kobayashi S,
Mitsumoto Y. Genetic influence of dopamine receptor, dopamine transporter, and nicotine metabolism on smoking cessation and nicotine dependence in a Japanese population. BMC Genet. 2014;15:151. doi: 10.1186/s12863-014-0151-2. 26. Shinohara M, Mizushima H, Hirano M, Shioe K, Nakazawa M, Hiejima Y, et al. Eating disorders with bingeeating behaviour are associated with the s allele of the 3'-UTR VNTR polymorphism of the dopamine transporter gene. J Psychiatry Neurosci. 2004;29(2):134-7. 